\title{
Michał Lachman*
}

(iD) https://orcid.org/0000-0002-6273-825X

\section{Humanistyka emancypacji, czyli przestrzenie życia i przestrzenie komunikacji między słowem a wirtualnością}

\author{
Streszczenie
}

Artykuł stanowi podsumowanie kilku sposobów rozumienia współczesnej humanistyki, której zasadniczą cechą pozostaje aspekt emancypacyjny oraz jej charakter relacyjny. Humanistyka postrzegana jest w tym kontekście nie tylko jako dyscyplina nauki zdominowana przez otwartość, ale przede wszystkim jako metodologia akceptująca własną nieostateczność. Ten element miękkiej strategii badawczej, w której ważnym aspektem refleksji pozostaje również doświadczenie osoby badającej, obecny jest $\mathrm{w}$ tych dziedzinach humanistyki, które łączą się z szeroko rozumianym obszarem kultury cyfrowej oraz wirtualnej rzeczywistości. Humanistyka badająca kulturę cyfrową zmuszona jest do redefinicji własnych narzędzi, a także do uznania innych podmiotów stanowiących źródło doświadczenia. Ten relacyjny charakter humanistyki, w którym ewoluuje ona ku wielości podmiotów i perspektyw badawczych stanowi zarówno wyzwanie, przed którym stają współcześni humaniści, jak i szansę dalszego rozwoju tej gałęzi nauki.

Słowa kluczowe: humanistyka, emancypacja, przestrzeń literacka, archiwum, krytyka genetyczna, kultura cyfrowa

* Prof. dr hab., Uniwersytet Łódzki, Wydział Filologiczny, Zakład Angielskiego Dramatu, Teatru i Filmu, ul. Pomorska 171/173, 91-404 Łódź; e-mail: michal.lachman@uni.lodz.pl 
Blok tekstów zamieszczony w tym numerze pisma, a także druga jego część planowana na numer kolejny, jest próbą ukazania badań humanistycznych w wymiarze zmiany i działania. Humanistyka, być może w sposób wyjątkowy i unikalny w stosunku do innych gałęzi nauki, nastawiona jest na zmianę. Zmianę nie tyle, bądź nie tylko, narzędzi badawczych, ale przede wszystkim własnych perspektyw i pozycji uprawiania działalności naukowej. Dziś być może silniej niż wcześniej od humanistyki powinniśmy wymagać nie obrony wartości istniejących, a rewizji aksjomatów, impulsu idącego ku odmianie i odnowie. Z tego wynika kilka założeń fundamentalnych, które nazwać można, idąc za określeniami użytymi przez Ingę Iwasiów w artykule otwierającym nasz wybór, humanistyką „nieostateczną” albo też humanistyką „emancypacji” („Humanistyka, zmiana, autobiografia. Studium przypadku osobistego"). Nie chodzi tu jedynie o założenie, że nauki humanistyczne w całej ich różnorodności nie mają prawa do ogłaszania wyników swoich badań w formie domkniętej, pewnej i niepodważalnej, że ich wkład jest mniej wartościowy wobec wymogów naukowego obiektywizmu w takim zakresie, jaki dziś jest w naukach obecny. Nie chodzi również o to, by zmieniać humanistykę w pole działań społecznych, które zadbają o dowartościowanie głosów marginalnych, kosztem uwagi poświęcanej tematom mainstreamowym. Wszystkie te założenia byłyby w dużej mierze próbą zdominowania humanistyki przez zewnętrzne wobec niej cele. Chodzi jednak o to, by uwrażliwić badaczy i badaczki na konieczność zmiany, płynności, czasami niemożności artykulacji, które są częścią składową poznania. Ten element „miękkiej” filozofii działania, o którym wzmiankuje Inga Iwasiów, a który w nieco innym kontekście rozwinięty zostaje w dalszych częściach naszego wyboru artykułów, stawia przed humanistyką szczególne wyzwania. Jest to przede wszystkim wyzwanie określenia własnej tożsamości wobec wymogów i oczekiwań stawianych przez inne dziedziny badań, a także systemowe rozwiązania panujące w badaniach naukowych i wreszcie pewne oczekiwania społeczne, werbalizowane niejednokrotnie w sposób bardzo zasadniczy i stanowczy. Jest to zatem dyskusja na temat niezależności humanistyki oraz tożsamości humanisty i humanistki.

Jest to zatem również humanistyka stawiająca w centrum własnych dociekań nie tyle „człowieka”, nie aż „Człowieka”, ile osobę konkretną, ja badacza i badaczki, podmiot piszący w danym momencie własnej refleksji, na konkretnym, zmiennym etapie działania. Cechą tego podmiotu w istotny sposób pozostają dwie przynajmniej wartości, a może raczej dwa sposoby zaangażowania; po pierwsze konieczność rewizji własnych ustaleń, skalowania i re-skalowania optyki oraz po drugie relacyjność wobec innych podmiotów, włączanie ich zmienności i płynności we własne założenia badawcze. W bezpośredni sposób postawa ta przejawia się w krytycznym namyśle nad własną drogą badawczą, w ponownym wielokrotnym czytaniu i odczytywaniu własnych diagnoz, w powrotach do tematów i ustaleń celem ich powtórnej rewizji, uwspółcześnienia, przemodelowania. Te wszystkie, jak ujmuje to Iwasiów „synonimy ruchu” obecne w słowniku nauki humanistycznej 
i w doświadczeniu tych, którzy i które ją uprawiają kierują nas w stronę z jednej strony pojęcia autobiografii $\mathrm{z}$ drugiej złożonej koncepcji archiwum i nadają im jednocześnie wymiar zarówno prywatny jak i publiczny.

Pojęcie autobiografii oraz insty tucja archiwum w oczywisty sposób dookreślają myślenie wobec granic własnych badawczych możliwości również w kontekście kontroli i nadzoru, instytucjonalnej władzy i osobistej odwagi. Jednym z aspektów Derridiańskiej koncepcji archiwum jest przecież jego normatywna funkcja, reguła kodyfikacji i prawodawstwa, imperatyw scalenia, efekt inskrypcji. Autobiografia zaś to parametr otwarty, skala nieskończoności, wyraz otwarcia. Na styku schematu, można powiedzieć na planie archiwalnego zbioru, skatalogowanego i zaopatrzonego w gotowe odsyłacze, podmiot badający dokonuje, znów słowami Iwasiów, swoistego „rozszczelnienia” systemu. A czyni to, dbając nie tyle o produkcję sensów i gotowych koncepcji, ile angażując się w ich długofalową „hodowlę”, bez uprzednich zobowiązań i następujących po nich oczekiwań.

Rysuje się w tym kontekście obraz humanistyki twórczych ucieczek i uników, ale nie rezygnacji z badawczego zaangażowania, raczej dyscypliny pełnej analitycznej „podejrzliwości”, której zamiarem pozostaje dookreślanie bardziej doświadczenia niż tożsamości. Zapisywanie „dokumentu swego stanu” widziane jako składnik badawczej strategii z jednej strony wychodzi przede wszystkim i na podstawowym poziomie ku badaniu materii, badaniu obiektu, badaniu rzeczy i przedmiotu, a nie fikcji, z drugiej strony otwiera na doznania intersubiektywne i relacyjne, gwarantuje spotkanie, komunikuje chęć rozmowy. W tak zarysowanym przez Ingę Iwasiów polu humanistyki mieszczą się pozostałe artykuły publikowane w tej części numeru. Opisując podmioty literackie i projektując własny podmiot badacza lub badaczki, włączają się właśnie w namysł nad dynamiką refleksji humanistycznej skonfrontowanej z niestałością własnych założeń i dogmatów. Tego rodzaju postawa nie jest w zasadniczej mierze utopijną ucieczką przed esencją, a jedynie opiera się na świadomości, że esencjonalność pozostaje zawsze i w każdym przypadku niedokończonym projektem i jeśli ma nie stać się prokrustowym łożem, musi pozostać twarzą Proteusza.

Zasadnicza dla tych rozważań jest kategoria miejsca oraz rysujące się od razu podstawowe rozróżnienie na jego wymiar geograficzny i literacki. Ma ono swoją wagę szczególnie w kontekście tworzenia, a przynajmniej współtworzenia, podmiotu - pisarskiego i literackiego - przez uwarunkowania przestrzenne. Związek pisarza z miejscem, które ma decydujący wpływ na jego twórczość i wyobraźnię nabiera szczególnego znaczenia w utworach takich autorów jak Gustaw Herling-Grudziński, którego biografia i doświadczenia życiowe związkom z miejscem nadają znaczenie fundamentalne (Katarzyna Sobota, „Miejsce jako czynnik sprawczy w twórczości Gustawa Herlinga-Grudzińskiego”). Przyjęta w tym przypadku przez Autorkę perspektywa zakłada właśnie takie dwukierunkowe oddziaływanie, w którym z jednej strony „»przestrzenne umiejscowienie« kształtuje człowieka, 
a z drugiej podmiot tworzy miejsce”. Zasadniczym założeniem wynikającym z analizy jednego utworu Herlinga-Grudzińskiego (Most. Z kroniki naszego miasta) jest również wizja podmiotu jako formy niestałej, podlegającej dynamicznym zmianom, receptywnej wobec bodźców zewnętrznych, ewoluującej i plastycznej. Dotyczy to zarówno samego pisarza, jako twórcy, na którym otoczenie oraz własna droga życiowa odciskają swoje piętno, jak i postaci literackich, które same dookreślają się wobec literackiej przestrzeni, a jednocześnie konkretyzują jej tożsamość w wyniku własnego w nią zaangażowania.

Stawiając tę kwestię w świetle teorii geopoetyki, Autorka zwraca uwagę na „aktywność miejsca w relacji z postacią" i prezentuje analizę opowiadania Herlinga-Grudzińskiego właśnie z perspektywy zmiany, która dokonuje się na styku działań i aktywności charakteryzujących zarówno postać, jak i przestrzeń. Dlatego tytułowy „most”, który przedstawia Herling-Grudziński w swoim opowiadaniu, wydobyty zostaje z niezróżnicowanej topografii miasta właśnie za sprawą obecności człowieka, przesiadującego na nim żebraka. Funkcja i charakter miejsca ulegają zmianie, jednocześnie jednak analogiczny proces zachodzi w przypadku bezdomnego, który czyniąc z mostu swój dom, sam wydobywa się z masy mieszkańców Neapolu, staje osobą rozpoznawalną, zyskuje nowe oblicze, przedstawia się innym od nowej strony. Ta relacyjność tożsamości, przestrzennej i ludzkiej, odniesiona jednocześnie do miejsc specjalnych, szczególnych, by nie powiedzieć za Foucaultem heterotopicznych jak kościół, cmentarz czy tawerna ustanawia nową perspektywę oglądu postaci, dopełnianej, definiowanej i niejako pisanej (zapisywanej, utrwalanej, archiwizowanej) wobec lokalnych oraz kulturowych narracji z tymi instytucjami związanych. Historia żebraka wraz z historią miejsc, w których pomieszkuje, piszą się od nowa, ujawniając konteksty i sensy niedostępne dla nich poza tą wzajemną relacją. Relacja ta zmienia i kształtuje obie strony, a człowiek odnajduje w tym sprzężeniu sensy skryte, sferę niedostępną innym, swoisty „anty-most", którego istnienie sam uwierzytelnia, w momencie kiedy skacze w jego otchłań, popełniając samobójstwo.

Proces kształtowania postaci literackiej, czy choćby głosu narratorskiego, za pośrednictwem czynności filtrujących oryginalne doświadczenie autora, świadomie bądź nie selekcjonującego i przetwarzającego obrazy zobaczone i przeżyte otwiera wiele ciekawych sposobów interpretacji działa. Sposoby integracji i przyswajania wielości ale też obcości doświadczenia, przerabiania go na materię literacką dookreślają model pisarski konkretnego autora, świadczą również o epoce, z którą jest związany. Samuel Beckett, funkcjonujący na granicy kultur i języków anglo-irlandzki pisarz, szczególnie ciekawe przetwarza surowy materiał obserwacji w obrazy literackie, zarówno w dramacie, jak i w powieści. Jego pisarstwo nadaje się do analiz genetycznych i archiwalnych nie tylko ze względu na obfite archiwa dokumentujące powstawanie jego dzieł na różnych etapach ich przygotowywania, ale również dlatego, że sam Beckett prowadził obfitą korespondencję nie tylko do- 
tyczącą własnej twórczości, ale i opisującą rozmaite przemyślenia, podróże, wizyty, spotkania, a wreszcie lektury. Materiał ten pozwala na analityczną rekonstrukcję procesu twórczego, daje sposobność odtworzenia mechanizmu przetwarzania myśli i doznań przeżytych w ich literacką, zapisaną formę.

James Little („Dekompozycja przestrzeni szpitalnej w Malone umiera Samuela Becketta: autor w świetle krytyki genetycznej”) definiuje tekst wąsko, jako sekwencję zapisanych słów, nie próbując rozciągać tego pojęcia na materię kultury, jej artefakty i praktyki. Definiując, czym jest tekst w sposób węższy, umożliwia jednocześnie swoim analizom badanie dokładnie tej granicy między językiem a rzeczywistością, która powstaje po dokonaniu wstępnego założenia o odrębności słowa i świata. Autor może dzięki temu także pokazać, w jaki sposób tacy twórcy jak Beckett przekraczają ową granicę i jak czyniąc to, zmieniają zarówno doświadczenie rzeczywistości, jak i sposoby pisania. Koncentrując swoje analizy na jednym temacie, ważnym dla Beckettowskiego pisarstwa, czyli na obrazach zakładów dla psychicznie chorych, Little bada, na czym polegał proces tworzenia się wyobrażeń o tych miejscach w twórczości autora Murphy'ego i Watta. Te dociekania mają na celu ukazanie nie tylko precyzyjnej, niemalże chirurgicznej, a przede wszystkim skrajnie minimalistycznej metody redukcji, jaką Beckett stosował przenosząc to, co obejrzane w sferę tekstu. Mają one także na celu wskazanie, jakie jest ostatecznie ulokowanie autora w tekście.

Różne są określenia na przejście doświadczenia ze stanu czystej obserwacji, zanotowanej w pisarskim dzienniku bądź liście w materię powieści i dramatu. Krytycy piszą o „rozmywaniu” detalu, zacieraniu śladów, redukcji szczegółu, czy dekompozycji świata. Wszystkie te zabiegi nabierają intensywności w przekładzie, którego jak wiadomo Beckett często sam się podejmował w przypadku własnych dzieł. Tam, przeskalowanie optyki i odsiewanie materiału stawało się dodatkowo skomplikowane, ponieważ zakładało również czynniki komunikacyjności w odmiennej kulturze. $Z$ tego obrazu wyłania się zdaniem Jamesa Little nie tylko ciekawa mapa twórczości, ale także bardzo złożony obraz pisarza zaangażowanego w systematyczne przerabianie własnej pamięci i doświadczenia, a zatem właśnie - o czym wspomniałem na początku w odniesieniu do ogólnych założeń humanistyki - pisarza przedstawiającego siebie w dynamicznej zmienności i niestałości własnego ja. Ja nieutrwalonego, ja amorficznego, które przemieszcza się między konkretyzującym obrazem a mgławicową konstelacją doświadczeń. W oczywisty sposób te jednostkowe procesy tworzenia siebie w dziele nie mogą przebiegać bez udziału, czy raczej znów dynamicznej obecności społecznego i kulturowego otoczenia, jakie stanowi dla pisarza bezpośredni materiał refleksji i podstawę percepcji rzeczywistości. Szczególnie w twórczości Becketta, zaopatrzonego intelektualnie w niewyczerpane pokłady ironii, koncepcja stałych pojęć kulturowych, niezmiennych tradycyjnych prawd, obrony wartości w stanie skodyfikowanym musi zostać poddana dekompozycji, a faktycznie po prostu ośmieszeniu. Postaci Becketta, jak i jego narratorzy, 
mogą co prawda usilnie poszukiwać ekwiwalentów niewzruszonych podstaw świata, ale w ostateczności niewiele jest im dane $\mathrm{z}$ tego, czego szukają.

W sposób naturalny więc, co zaznacza James Little, strategie kompozycyjne Becketta są w rzeczywistości obrazem jego bardziej lub mniej skrywanego światopoglądu. $\mathrm{Z}$ analiz notatników pisarskich, dzienników i korespondencji wyłania się szczególny obraz twórczości, w której świat i jego założenia podtrzymywane są przy życiu przez ciągłą analizę oraz obsesyjne przyglądanie się temu jak obumierają.

W kierunku rozmontowywania stałej i stabilnej konstrukcji ja mówiącego, czy też ja badającego idzie refleksja, która łączy humanistykę z wirtualną rzeczywistością. W tej sferze realnie zmienia się otoczenie, w którym porusza się świadomość badacza, a także która konstruuje podstawowy materiał stanowiący przedmiot analizy. Jak podkreśla Mateusz Markowski („System VR - nowa przestrzeń komunikacyjna”), cechą wyróżniającą wirtualną rzeczywistość jest to, że „umieszcza rzeczywisty umysł w stymulowanym komputerowo świecie" zamiast wprowadzać w świat człowieka element sztucznej inteligencji. Ta zmiana odwraca zatem zależność badacz-przedmiot, odbierając temu pierwszemu pełną kontrolę i przewage na badaną materią. Właśnie z tego powodu, badacz kultury cyfrowej musi dysponować repertuarem narzędzi i kompetencji odmiennym od zwykłego aparatu pojęciowego zazwyczaj wykorzystywanego w humanistyce. Połączenie kompetencji miękkich i twardych, jak podkreśla Anna Paprzycka („Znaczenie praktyki dla badacza kultury cyfrowej”), staje się koniecznością niemal we wszystkich kierunkach badań nad współczesną kulturą.

Szczególnie w ramach badań humanistycznych daje o sobie znać konieczność nawiązywania dialogu między tą dziedziną a naukami ścisłymi. Idąc za tezami Ryszarda Kluszczyńskiego, Autorka podkreśla również znaczenie pluralizacji i hybrydyzacji zarówno kultury, jak i prowadzonych badań, które niejednokrotnie przyjmują formę fraktalną. W tym otwartym i pluralistycznym środowisku tworzy się przestrzeń dla sfery, którą Anna Paprzycka za C.P. Snowem nazywa trzecią kulturą. Charakteryzuje tę dziedzinę nie tylko analityczne odejście od binarnych podziałów w odczytywaniu zjawisk i klasyfikowaniu problemów, ale model komunikacji obejmujący skontrastowane ze sobą wcześniej dyskursy należące do humanistyki i nauk ścisłych. O zupełnie innych warunkach komunikacji, o których wspomina w swoim artykule Mateusz Markowski, podkreślając znaczenie dla sfery publicznej produktów wykorzystujących wirtualną rzeczywistość, można zatem mówić i w tym szerokim badawczym wymiarze dotyczącym zasadniczo całości współczesnej, w dużej mierze cyfrowej kultury. Powstające w różnych miejscach i afiliowane przy instytucjach badawczych medialaby, mają na celu właśnie umożliwienie wymiany naukowej między badaczami z różnych dziedzin, a na tak przygotowanym gruncie, o czym wzmiankuje Anna Paprzycka, spotykają się literaturoznawcy, kulturoznawcy, informatycy i fizycy. Jak się zdaje, konkluzja artykułu Anny Paprzyckiej może posłużyć za trafne podsumowanie całego mode- 
lu humanistyki, który znajduje w tym zbiorze artykułów swoje odbicie. Jak pisze Autorka: „humanistyka uprawiana według takich założeń obala pułapkę myślową polegającą na traktowaniu metodologii i wyników badań naukowych jako narzędzi umożliwiających obiektywne poznanie rzeczywistości”.

Zasadniczo ten obraz humanistyki modeluje również pozycję i postawę humanisty i humanistki. Postawy, która nastawiona jest właśnie na to, co Inga Iwasiów nazywa „przechodniością" i „nieostatecznością metodologii humanistycznych”. Tak rozumianej postawie badawczej towarzyszy charakterystyczny dla niej „,namysł autobiograficzny”, który niweluje nie tylko, znów słowami Iwasiów „dogmat obiektywizmu”, ale zapewnia nauce ruch i ruchliwość, dynamikę i gotowość do zmiany, nie odbierając jej przy tym komunikacyjnych narzędzi gwarantujących weryfikowalność jej ustaleń i zapewniających kod porozumienia z innymi dyscyplinami. Kto wie, czy rolą i funkcją humanistyki nie pozostaje właśnie ciągłe bycie pomiędzy, wieczne nienależenie do żadnego języka, plemienia, narodu, a zatem forma dezorientacji, która zastępuje orientowanie się na znane, a co gorsze wyznaczane, punkty, trajektorie, cele.

Michał Lachman

\title{
Emancipating humanities: communicating between the real and the virtual
}

\author{
Summary
}

The article offers a summary of a number of approaches to contemporary humanities in which the main dynamics of research and methodology could be characterised as emancipation. The humanities is seen here not merely as an open discipline, but it is viewed as a method of research able of accepting its relational and indeterminate progress. The soft dimension of its analysis, which is also rooted in an individual biography of the researcher, results from a particular attention paid to other than human subjects. In particular, the humanities related to digital culture and virtual reality needs to redefine its research methods but also communicate with other sources of perception and experience. This relational nature of contemporary humanities in which it reflects the complexity of multiple subjects and perspectives challenges more traditional positions of analysis but simultaneously offers a chance of development.

Keywords: humanities, emancipation, fictional space, archive, genetic criticism, digital culture 
Michał Lachman, kierownik Zakładu Angielskiego Dramatu, Teatru i Filmu Uniwersytetu Łódzkiego. Zajmuje się historią i teorią współczesnego teatru i dramatu brytyjskiego oraz irlandzkiego. Opublikował Brzytwa po oczach. Młodzi doświadczeni $w$ angielskim $i$ irlandzkim dramacie lat dziewięćdziesiątych (Kraków 2007) i Performing Character in Contemporary Irish Drama (Palgrave 2018). Jest autorem przekładów książek Williama Hogartha, Analiza piękna (Gdańsk 2008) i Eli Rozika, Korzenie teatru (Warszawa 2011) oraz tłumaczeń dramatów: Billy Roche’a, Christiny Reid (Kraków 2009) i Franka McGuinnessa (Warszawa 2012). Współpracuje z „Dialogiem” i „Didaskaliami”. Prowadzi stronę „Łódź w Kulturze”, na której publikuje recenzje teatralne. 